\title{
The effect of perioperative electrolyte, acid-base balance, hemodynamic data and anesthetic management on early mortality of patients with small bowel transplantation
}

\section{İnce bağırsak transplantasyonu uygulanan hastaların perioperatif elektrolit, asit-baz dengesi, hemodinamik verilerinin ve anestezik yönetiminin erken mortalite üzerine etkisi}

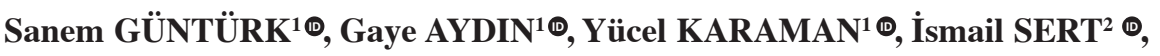 \\ Cem TUĞMEN ${ }^{2} \oplus$, Eyüp KEBAPÇI ${ }^{2 \oplus}$, Ayşe Pervin SÜTAŞ BOZKURT ${ }^{1 \oplus}$
}

1Să̆llk Bilimleri Üniversitesi, Tepecik Ĕ̈itim Araştırma Hastanesi, Anesteziyoloji ve Reanimasyon Kliniği, İzmir, Türkiye

2Să̆lık Bilimleri Üniversitesi, Tepecik Ĕ̆itim Araştırma Hastanesi, Genel Cerrahi Kliniği, İzmir, Türkiye

\section{ABSTRACT}

\begin{abstract}
Objective: Due to high mortality rates, small bowel transplantation is a rarely applied intervention. In this study, we aimed to investigate the effects of perioperative hemodynamic data, electrolyte balance and blood gas parameters on early period mortality of the patients who underwent small bowel transplantation.

Methods: The data of 23 patients, who had undergone small bowel transplantation in our clinic between 2004 and 2016, were examined retrospectively. All the patients' demographic data, causes of small bowel syndrome, perioperative hemodynamic data, electrolyte and blood gas values, blood replacement and early postoperative mortality rates within 48 hours were recorded. Statistical analysis was used to identify the parameters that effected early mortality.

Results: The mean age of the 23 patients ( 13 female, and 10 male) was $34.54 \pm 15.2$ years. Early period mortality was identified in four patients. When comparing demographic and clinic data with mortality, no statistically significant difference was found. There was a significant difference in $\mathrm{pH}$, HCO3, BE values before and after reperfusion. No significant difference was found between electrolyte, blood gas values and early period mortality in the comparison of the same data.

Conclusion: Many variables effect mortality in small bowel transplantation patients. We think that hemodynamic and metabolic changes should be monitored carefully in perioperative period to avoid early period mortality.
\end{abstract}

Keywords: Anesthesia, intestinal, mortality, small bowel, transplantation

$\ddot{\mathbf{O Z Z}}$

\begin{abstract}
Amaç: Yüksek mortalite oranları nedeniyle ince bağırsak transplantasyonu oldukça nadir olarak uygulanan bir girişimdir. Bu çalışmada, ince barsak transplantasyonu uygulanan olguların peroperatif dönemdeki hemodinamik verilerini, elektrolit yönetimini, kan gazı değerlerinin erken dönem mortalite üzerine etkilerini araştırmayı amaçladık.

Yöntem: 2004-2016 yılları arasında hastanemiz kliniğimizde ince barsak transplantasyonu operasyonu yapılmış olan 23 hastanın verileri retrospektif olarak incelendi. Tüm hastaların demografik verileri, kısa bağırsak sendromu nedenleri, peroperatif hemodinamik verileri, kan gazı değerleri, kan replasmanı ve postoperatif ilk 48 saat erken dönem mortalite oranları kaydedildi. Mortaliteyi etkileyen parametreleri tanımlamak için istatistiksel analiz yapıldı.

Bulgular: Hastaların yaş ortalaması $34,54 \pm 15,2$ olup, 13 'ü kadın, 10'u erkek hastaydı. Erken dönem mortalite toplam 4 hastada gerçekleşti. Mortalite ile demografik ve klinik veriler karş1laştırıldığında istatistiksel olarak fark saptanmadı. Kan gazı ve elektrolit değerlerinin reperfüzyon öncesi ve sonrası karşılaştırılmasında sodyum, pH, HCO3, BE değerleri arasında anlaml fark vardı. Aynı veriler erken dönem mortalite ile karşılaştırıldığında ise istatistiksel olarak anlamlı fark saptanmadı.

Sonuȩ: İnce bağırsak transplantasyonu yapılan hastalarda mortalite üzerinde birçok değiişen mevcuttur. Erken dönem mortaliteyi azaltmak açısından peroperatif dönemde hemodinamik ve metabolik değişikliklerin dikkatle izlenmesi gerektiğini düşünmekteyiz.
\end{abstract}

Anahtar kelimeler: Anestezi, ince bağırsak, mortalite, transplantasyon
Alındığı tarih: 08.10.2018

Kabul tarihi: 29.10 .2018

Yazışma adresi: Uzm. Dr. Sanem Güntürk, İzmir Tepecik Eğitim ve Araştırma Hastanesi Anestezi Kliniği, İzmir - Türkiye

e-mail: drsanem101@hotmail.com

Yazarlarm ORCID bilgileri:

S.G. 0000-0001-6656-1140 G.A. $0000-0003-1441-9462$

Y.K. 0000-0002-4689-712X

İ.S. 0000-0001-5190-9124

C.T. 0000-0002-2668-5197

E.K. 0000-0001-8900-2325

A.P.S.B. 0000-0002-2073-826X 


\section{INTRODUCTION}

Intestinal failure can occur after extensive resection of small intestine being done for various reasons or it can occur due to functional small intestine failure caused by Hircshsprung disease, necrotizing enterocolitis, and pseudo obstruction. The chance of 1-3 years of survival time for the patients with intestinal failure was reported as \%75-82 ${ }^{(1)}$. Small bowel transplantation (SBTx) has quickly become the preferred therapy for short bowel syndrome ${ }^{(2,3)}$. Surgical techniques, immunosuppressants and improvements in anesthetic management have made small bowel transplantation a standard treatment for patients with irreversible intestinal failure who can't continue to receive total parental nutrition treatment ${ }^{(2)}$. Due to the difficulties of the treatment and monitoring of surgical, metabolic, immunologic, functional, infectious and nutritional complications, small bowel transplantation is still considered as a challenging process considering its preoperative and postoperative period.

Anesthetic management of patients with small bowel translantation involves several difficulties. Because of blood losses, dehydration, long ischemia times and loss in third space, fluid-electrolyte disorders may occur. Hypotension with mean arterial pressure less than $60 \mathrm{~mm} \mathrm{Hg}$ is defined as the "postreperfusion syndrome" (PRS) and it may occur in small bowel transplant recipient patients ${ }^{(4)}$. The most critical stage during small bowel transplantation appears to be after graft reperfusion. Ischemia and organ reperfusion are associated with the release of proinflammatory mediators, formation of free radicals, and neutrophilic activation. These substances become important related with the state of the graft after reperfusion ${ }^{(3)}$. In addition, hemodynamic changes that occur during transplantation may also trigger postreperfusion syndrome ${ }^{(3,5)}$. In this hypotensive period, management of fluid and electrolyte disorders that may effect graft survival is important ${ }^{(4)}$.

In our study we aimed to investigate the effects of hemodynamic data, electrolyte values on early period mortality during perioperative period of the patients who had undergone small bowel transplantation between 2004 and 2016 in our hospital which is an important center in our country.

\section{MATERIAL and METHODS}

After having the approval of the local ethics committee of our hospital, perioperative anesthesia records and daily follow-up files of the patients who had undergone SBTx from 2004 to 2016 were examined retrospectively. A total of 24 patients were planned to be included in the study. However, one case was excluded due to missing perioperative data. Demographic data of all cases, causes of small bowel syndrome, hemodynamic data before and after reperfusion during the perioperative period, blood gas and electrolyte changes, central venous pressure values, blood and blood product replacement therapy and postoperative early (first 48 hours) and late mortality rates after small bowel transplantation were recorded.

In all cases, central venous catheterization, invasive arterial and heat monitoring were performed in addition to standard American Society of Anesthesiology (ASA) monitoring criteria. In these cases, intravenous (IV) bolus doses of propofol and fentanyl were used for induction of anesthesia and iv rocuronium was administered after adequate muscle relaxation. Anesthesia administration was achieved with $50 \% \mathrm{O}_{2}$ and $1 \mathrm{MAC}(2 \%)$ in the air mixture with sevoflurane and remifentanil infusion in patients whose hemodynamic response was adequate. After induction of anesthesia, arterial and central venous catheterization was performed and continuous invasive arterial monitorization and central venous pressure measurement were monitored. It was stated in the anesthesia follow up papers that the catheter was placed by the help of ultrasound to the patients in whom it was difficult to place the central catheter.

Age, gender, duration of operation, cold ischemia time, causes of small bowel syndrome, $\mathrm{Na}^{+}, \mathrm{K}^{+}$values central venous pressure (CVP) measurements, blood gas values before and after reperfusion, the 
length of time when the mean arterial pressure was under $60 \mathrm{mmHg}$ during the perioperative period of all patients and blood transfusion or inotropic support provided for these patients (if any were recorded). The periods when the mean arterial pressure dropped below $60 \mathrm{mmHg}$ were considered to be hypotensive period. All these data were compared with the postoperative 48-hour early mortality rate. All cases were sent to the anesthesia intensive care unit for intensive postoperative monitoring at the end of the operation.

\section{Statistical Analysis}

The normality of distribution of continuous variables was tested by Shaphiro- Wilk test. To compare 2 dependent groups for numerical variables Paired sample $t$ (for normal distributed data) or Wilcoxon (for non-normal distributed data) tests were used. Univariate
Binary Logistic regression analysis was applied to estimated ORs and 95\% CIs. Statistical analysis was performed with SPSS for Windows version 24.0 and a $p$ value $<0.05$ was accepted as statistically significant.

\section{RESULTS}

Mean age of 23 (13 women and 10 men) patients was $34 \pm 15$ (range 6 months - 56 years) years, while 5 patients were under 18 years old (pediatric patients). One of the children was 6 months old and others were 12-16 years old. Eighteen patients were over 18 years of age (range, 24 to 56 years). The mean duration of operation was 402.17 \pm 102.4 minutes and the mean duration of cold ischemia was $368.91 \pm 107.259$ minutes. In the perioperative period, erythrocyte suspensions and fresh frozen plasma

Table 1. Summary of data for all SBTx cases.

\begin{tabular}{|c|c|c|c|c|c|}
\hline Parameter & & Min-Max & Mean \pm SD & $\%$ & (n) \\
\hline Age (years) & & $0.5-56$ & $34.54 \pm 15.20$ & & 23 \\
\hline \multirow[t]{2}{*}{ Gender } & Female & & & 56,5 & 13 \\
\hline & Male & & & 43,5 & 10 \\
\hline \multirow[t]{9}{*}{ Before Reperfusion } & Sodium $\left(\mathrm{Na}^{+}\right)$ & $126-145$ & $135.91 \pm 4.28$ & & 23 \\
\hline & Potasyum $\left(\mathrm{K}^{+}\right)$ & $2.10-5.50$ & $3.91 \pm 0.96$ & & 23 \\
\hline & $\mathrm{pH}$ & $7.29-7.62$ & $7.39 \pm 0.08$ & & 23 \\
\hline & $\mathrm{PaO}_{2}$ & $62.0-279.0$ & $173.85 \pm 57.76$ & & 23 \\
\hline & $\mathrm{PCO}_{2}^{2}$ & $20.80-42.50$ & $34.63 \pm 5.44$ & & 23 \\
\hline & $\mathrm{O}_{2}$ Sat & $87.6-100.0$ & $98.64 \pm 2.48$ & & 23 \\
\hline & $\mathrm{HCO}_{3}^{2}$ & $15.10-28.60$ & $21.65 \pm 3.50$ & & 23 \\
\hline & $\mathrm{BE}$ & $-9.9-6.50$ & $-2.4 \pm 4.6$ & & 23 \\
\hline & $\mathrm{CVP}(\mathrm{mmHg})$ & 3-11 & $7.57 \pm 2.62$ & & 23 \\
\hline \multirow[t]{9}{*}{ After Reperfusion } & Sodium $\left(\mathrm{Na}^{+}\right)$ & $132-148$ & $138.17 \pm 3.72$ & & 23 \\
\hline & Potasium $\left(\mathrm{K}^{+}\right)$ & $2.8-4.87$ & $3.96 \pm 0.65$ & & 23 \\
\hline & $\mathrm{pH}$ & $7.00-7.46$ & $7.30 \pm 0.093$ & & 23 \\
\hline & $\mathrm{PaO}_{2}$ & $56.0-309.0$ & $183.62 \pm 71.35$ & & 23 \\
\hline & $\mathrm{PCO}_{2}$ & $26.90-50.20$ & $35.98 \pm 6.30$ & & 23 \\
\hline & $\mathrm{O}_{2}$ Sat & $91.0-100.0$ & $98.67 \pm 2.01$ & & 23 \\
\hline & $\mathrm{HCO}_{3}^{2}$ & $14.90-28.40$ & $19.13 \pm 3.39$ & & 23 \\
\hline & $\mathrm{BE}^{3}$ & $-11.70-4.60$ & $-6.65 \pm 4.15$ & & 23 \\
\hline & $\mathrm{CVP}(\mathrm{mmHg})$ & $0-9$ & $4.39 \pm 2.65$ & & 23 \\
\hline Lenght of operation (min) & & $190-660$ & $402.17 \pm 102.40$ & & 23 \\
\hline Cold ischemia time (min) & & $60-540$ & $368.91 \pm 107.25$ & & 23 \\
\hline Periop MAP<60 time (min) & & $10-50$ & $31.52 \pm 12.47$ & & 23 \\
\hline Periop HR(rate/min) & & $80-140$ & $105.96 \pm 16.72$ & & 23 \\
\hline Periop SAP (mmHg) & & $80-180$ & $121.74 \pm 31.39$ & & 23 \\
\hline Periop DAP (mmHg) & & $40-110$ & $70.22 \pm 17.93$ & & 23 \\
\hline \multirow[t]{2}{*}{ Periop Blood - FFP infusion } & Yes & & & 56.5 & 13 \\
\hline & No & & & 43.5 & 10 \\
\hline \multirow[t]{2}{*}{ Periop inotrop use } & Yes & & & 8.7 & 2 \\
\hline & No & & & 91.3 & 21 \\
\hline \multirow[t]{2}{*}{ Early period mortality } & Yes & & & 17.4 & 4 \\
\hline & No & & & 82.6 & 19 \\
\hline
\end{tabular}

SD:standard deviation, CVP: central venous pressure, MAP: mean arterial pressure, HR: heart rate, SAP:systolic arterial pressure, DAP: dyastolic arterial pressure, FFP: fresh frozen plasma 
(FFP) transfusions were performed in 13 cases. In perioperative period, vasoconstrictor drug was used only in two patients. While the mean pre reperfusion CVP level of the patients was $7.57 \pm 2.63 \mathrm{mmHg}$, it was found as $4.39 \pm 2.66 \mathrm{mmHg}(0-9 \mathrm{mmHg})$ after reperfusion. Hemodynamic, metabolic, electrolyte analyses are also recorded in Table 1.

The most common indication for small bowel transplantation was intestinal ischemia (Table 2).

Out of 23 cases 7 female, and 9 male patients

Table 2. Reason of short bowel syndrome.

\begin{tabular}{lcc}
\hline Reason & Number of Cases (n) & $(\%)$ \\
\hline Mesenteric Ischemia & 13 & 56.5 \\
Crohn disease & 3 & 13.0 \\
Agangliosis & 1 & 4.3 \\
Gunshot wound & 1 & 4.3 \\
Surgical complication & 1 & 4.3 \\
Malrotation & 2 & 8.7 \\
Buerger disease & 0 & 0.0 \\
Rejection & 1 & 4.3 \\
Mesenchymal tumor & 1 & 4.3 \\
\end{tabular}

died. Etiologic factors for mortality were sepsis $(n=7)$, organ rejection $(n=3)$, vascular thrombosis $(n=2)$, acute lung injury $(n=1)$, pulmonary embolism $(\mathrm{n}=1)$, graft thrombosis $(\mathrm{n}=1)$ and hepatic encephalopathy $(n=1)$. Within the first 48 hours, 4 patients exited. None of the patients died during intestinal surgery. Mean age of the exited patients within the first 48 hours was $44 \pm 8,28$ years (range, 37-56 years). The causes of mortality were sepsis $(n=3)$, and graft thrombosis $(n=1)$. Two patients died within postoperative 2-30 day, and 10 patients within postoperative 30 days- 6 months. 7 patients were alive by the time of this study. In pediatric cases survival times for 6-months-old, and 12-year-old patients were 51 and 4 days, respectively while the other patients still survived at the time of this study. There was no significant difference between early period mortality and the parameters of the patients (Table 3). As a result of comparison of blood gas values before and after reperfusion, there was a statistically significant diffe-

Table 3. Comparison of parameters with early period mortality.

\begin{tabular}{|c|c|c|c|c|c|c|c|}
\hline \multirow[b]{2}{*}{ Parameter } & & \multicolumn{2}{|c|}{ Mortality } & \multirow[b]{2}{*}{$\mathbf{p}$} & \multirow[b]{2}{*}{ OR } & \multicolumn{2}{|c|}{ CI \%95 for OR } \\
\hline & & Yes $($ Mean \pm SD) & No $($ Mean \pm SD $)$ & & & Lower & Upper \\
\hline Age (years) & & $44 \pm 8.29$ & $32.55 \pm 15.72$ & 0.197 & 1.076 & 0.963 & 1.202 \\
\hline Gender & Female & 2 & $\begin{array}{c}11 \\
8\end{array}$ & 0.773 & 1.375 & 0.158 & 11.937 \\
\hline \multirow{9}{*}{ Before Reperfusion } & Sodium $\left(\mathrm{Na}^{+}\right)$ & $134.5 \pm 3.7$ & $136.21 \pm 4.43$ & 0.464 & 0.910 & 0.708 & 1.170 \\
\hline & Potasium $\left(\mathrm{K}^{+}\right)$ & $4.28 \pm 0.99$ & $3.83 \pm 0.97$ & 0.403 & 1.650 & 0.510 & 5.343 \\
\hline & $\mathrm{pH}$ & $7.36 \pm 0.06$ & $7.4 \pm 0.08$ & 0.318 & 0.000 & 0.000 & 0.000 \\
\hline & $\mathrm{PaO}_{2}$ & $127.5 \pm 44.79$ & $183.62 \pm 56.27$ & 0.101 & 0.979 & 0.955 & 1.004 \\
\hline & $\mathrm{PCO}_{2}$ & $38 \pm 4.51$ & $33.92 \pm 5.45$ & 0.185 & 1.217 & 0.910 & 1.626 \\
\hline & $\mathrm{O}_{2}$ Sat $^{2}$ & $96.23 \pm 5.76$ & $99.15 \pm 0.66$ & 0.318 & 0.626 & 0.250 & 1.570 \\
\hline & $\mathrm{HCO}_{3}^{2}$ & $21.53 \pm 5.55$ & $21.68 \pm 3.14$ & 0.935 & 0.987 & 0.719 & 1.354 \\
\hline & $\mathrm{BE}$ & $-3.28 \pm 5.98$ & $-2.22 \pm 4.45$ & 0.671 & 0.947 & 0.738 & 1.216 \\
\hline & $\mathrm{CVP}(\mathrm{mmHg})$ & $7.5 \pm 3.42$ & $7.58 \pm 2.55$ & 0.955 & 0.988 & 0.650 & 1.502 \\
\hline \multirow[t]{9}{*}{ After Reperfusion } & Sodium $\left(\mathrm{Na}^{+}\right)$ & $137.25 \pm 1.26$ & $138.37 \pm 4.06$ & 0.579 & 0.913 & 0.661 & 1.261 \\
\hline & Potasium $\left(\mathrm{K}^{+}\right)$ & $4.42 \pm 0.4$ & $3.88 \pm 0.67$ & 0.161 & 6.417 & 0.477 & 86.406 \\
\hline & $\mathrm{pH}$ & $7.25 \pm 0.17$ & $7.31 \pm 0.07$ & 0.263 & 0.001 & 0.000 & 0.001 \\
\hline & $\mathrm{PaO}_{2}$ & $135.5 \pm 65.28$ & $193.76 \pm 69.93$ & 0.158 & 0.986 & 0.967 & 1.005 \\
\hline & $\mathrm{PCO}_{2}$ & $34.33 \pm 8.12$ & $36.34 \pm 6.07$ & 0.557 & 0.944 & 0.780 & 1.144 \\
\hline & $\mathrm{O}_{2}$ Sat & $96.88 \pm 3.95$ & $99.05 \pm 1.21$ & 0.121 & 0.653 & 0.381 & 1.119 \\
\hline & $\mathrm{HCO}_{3}^{2}$ & $20.05 \pm 1.68$ & $18.94 \pm 3.66$ & 0.550 & 1.098 & 0.808 & 1.493 \\
\hline & $\mathrm{BE}$ & $-4.53 \pm 3.61$ & $-7.09 \pm 4.21$ & 0.271 & 1.151 & 0.896 & 1.479 \\
\hline & $\mathrm{CVP}(\mathrm{mmHg})$ & $4.5 \pm 3.11$ & $4.37 \pm 2.65$ & 0.927 & 1.020 & 0.673 & 1.544 \\
\hline \multicolumn{2}{|c|}{ Lenght of operation (min) } & $416.25 \pm 196.02$ & $399.21 \pm 79.74$ & 0.758 & 1.002 & 0.991 & 1.013 \\
\hline \multicolumn{2}{|c|}{ Cold ischemia time (min) } & $412.5 \pm 68.5$ & $359.74 \pm 113$ & 0.369 & 1.006 & 0.993 & 1.020 \\
\hline \multicolumn{2}{|c|}{ Periop MAP<60 time (min) } & $36.25 \pm 11.81$ & $30.53 \pm 12.68$ & 0.404 & 1.043 & 0.945 & 1.151 \\
\hline \multicolumn{2}{|c|}{ Periop HR (rate/min) } & $113 \pm 4.76$ & $104.47 \pm 18.02$ & 0.355 & 1.032 & 0.965 & 1.104 \\
\hline \multicolumn{2}{|l|}{ Periop SAP (mmHg) } & $132.5 \pm 35.94$ & $119.47 \pm 30.95$ & 0.448 & 1.014 & 0.979 & 1.050 \\
\hline \multicolumn{2}{|l|}{ Periop DAP (mmHg) } & $68.75 \pm 20.16$ & $70.53 \pm 18.02$ & 0.854 & 0.994 & 0.935 & 1.058 \\
\hline
\end{tabular}

Fisher's Exact test, Mann Whitney u test. SD: standard deviation, CVP: central venous pressure, MAP: mean arterial pressure, HR: heart rate, SAP:systolic arterial pressure, DAP: dyastolic arterial pressure, OR: Odds ratio, CI: Confidence interval. 
rence in $\mathrm{pH}, \mathrm{HCO}_{3}, \mathrm{BE}$ and $\mathrm{Na}^{+}(\mathrm{p}<0.001 ; 0.006$ $0.005 ; 0.02$, respectively) (Table 4 ).

Table 4. Comparison of blood gas values between before and after reperfusion.

\begin{tabular}{lccc}
\hline Parameters & $\begin{array}{c}\text { Before Reperfusion } \\
(\mathbf{n = 2 3})\end{array}$ & $\begin{array}{c}\text { After Reperfusion } \\
(\mathbf{n = 2 3})\end{array}$ & $\mathbf{P}$ \\
\hline Sodium $\left(\mathrm{Na}^{+}\right)$ & $135.91 \pm 4.28$ & $138.17 \pm 3.73$ & $0.020^{*}$ \\
Potasium $\left(\mathrm{K}^{+}\right)$ & $3.91 \pm 0.96$ & $3.97 \pm 0.66$ & 0.746 \\
$\mathrm{pH}$ & $7.39 \pm 0.08$ & $7.3 \pm 0.09$ & $0.001^{*}$ \\
$\mathrm{PaO}_{2}$ & $173.86 \pm 57.77$ & $183.63 \pm 71.36$ & 0.309 \\
$\mathrm{PCO}_{2}$ & $34.63 \pm 5.44$ & $35.99 \pm 6.31$ & 0.376 \\
$\mathrm{O}_{2} \mathrm{Sat}$ & $98.64 \pm 2.48$ & $98.67 \pm 2.01$ & 0.918 \\
$\mathrm{HCO}^{3}$ & $21.65 \pm 3.5$ & $19.13 \pm 3.4$ & $0.006^{*}$ \\
$\mathrm{BE}$ & $-2.4 \pm 4.61$ & $-6.65 \pm 4.15$ & $0.005^{*}$ \\
& & & \\
\hline
\end{tabular}

$p<0.05$ was accepted as statistically significant. Wilcoxon Signed Rank analyses

\section{DISCUSSION}

During the perioperative period, fluid and electrolyte management, vasoconstrictor drug use, transfusion of blood and blood products if necessary, and postoperative pain treatment are effective on postreperfusion graft survival ${ }^{(1,2,6-8)}$.

Experimental studies were done on different animals in various centers, and provided the necessary skills in SBTx. Clark et al. ${ }^{(5)}$ used the pig model, which has the closest metabolism to humans, in their animal studies, and evaluated hemodynamic, metabolic and electrolyte changes in the perioperative period of the immune suppressed group and the untreated group after graft reperfusion. As a result, they stated that whether immune suppressive treatment is used or not, hemodynamic, metabolic and electrolyte changes as a part of anesthetic procedure particularly after reperfusion period have a positive effect on graft survival. In our study, we identified that patients died during early postoperative period were older with increased operative, and cold ischemia times. Siniscachi et al. showed that the small difference in cold ischemia time between patients did not have a significant effect on metabolic parameters ${ }^{(7)}$. In our study, we found that the duration of cold ischemia was longer in patients with early mortality. Maintenance of normal electrolyte composition, par- ticularly potassium, is also important. Potassium levels should be kept below $4 \mathrm{mEq} / \mathrm{L}$ before reperfusion to avoid potential cardiac dysrhythmias (9). Increase in potassium levels after revascularization may be caused by the release of metabolic products from the donor intestine and the change in potassium levels may also effect the $\mathrm{pH}$ and cause acidosis to develop ${ }^{(7)}$. In our study, we found that potassium levels after reperfusion were high in patients who developed early mortality, but $\mathrm{PaO}_{2}$ (partial oxygen pressure) values were low. Although these parameters were statistically insignificant, we think they are clinically important. This may be the result of our low number of cases.

In anesthetic management ischemia-reperfusion injury is important. Oxidative stress response may occur when blood flow into ischemic organ starts inducing release of endogenous and exogenous substances. The immune response is triggered and may cause graft rejection. Studies with remifentanil have shown that this agent reduces ischemia-reperfusion injury by reducing systemic inflammatory damage in the bowel ${ }^{(10,11)}$. During reperfusion in order to reduce the ischemic damage to minimum, the patient should be optimized metabolically. Arterial blood gases, electrolytes, hematocrit and coagulation should be monitored frequently. The mean arterial pressures (MAPs) falling under $60 \mathrm{mmHg}$, which is defined as a post reperfusion syndrome, were identified in $47 \%$ of the cases. This hypotensive period is believed to be the result of combination of hyperkalemia, acidosis, hypothermia, and then vasoactive substances such as free radicals, endotoxin and inflammatory cytokines released by the graft or intestine. Post-reperfusion syndrome has been reported to increase the rate of severe renal failure and mortality (3). In our study, there were only 2 cases in need of inotropic support. Only in one of the early stage mortality cases, both blood and blood products were transfused and inotropic agent support was provided. In cases of early mortality, it was observed that the perioperative hypotensive period was longer in our study. However, there was no significant difference. 
Isolated bowel transplantation allows patients with irreversible small bowel failure to be weaned from total parental nutrition (TPN) and reach a survival rate of $92 \%$ after 5 years. During SBTx, anesthetic management poses many difficulties. Hepatobiliary dysfunction is observed in many patients with longterm TPN. There can be difficulties in catheter placement and vascular access and sepsis potentially due to catheter contamination ${ }^{(4)}$. In our study, we didn't find out an infection sign or liver failure in the laboratory evaluations. Ultrasound helps us in difficult central catheter interventions.

In the field of SBTx, regarding anesthetic approach, Dalal focused on the difficulty of central venous access. In addition, he mentioned the use of volatile agents such as sevoflurane and isoflurane, narcotics and non-depolarizing muscle relaxants during SBTx (10). He emphasized the preference of remifentanil which is eliminated by plasma esterases and atracurium and cis-atracurium, which are cleared by Hoffman elimination and ester hydrolysis respectively, in patients with hepatic failure ${ }^{(10)}$. In our study, we detected that propofol, fentanyl, and rocuronium were used as muscle relaxants in SBTx patients. During the perioperative period, infusion of remifentanil was applied and the anesthesia was maintained with sevoflurane.

In case of tissue rejection due to ischemia reperfusion injury, overall mortality and morbidity rate was reported as $50-75 \%$ of acute rejection and $15 \%$ of chronic rejection ${ }^{(12)}$. Chronic rejection was detected in our 3 cases whom we monitored respectively.

In a study conducted by Siniscalchi et al. ${ }^{(7)}$ on 27 cases, successful monitoring of hemodynamic, metabolic and coagulation parameters and accurate anesthetic management in SBTx were emphasized. Since SBTx, is not a common surgical procedure, more cases are needed for these changes to be associated with ischemia-reperfusion injury.

SBTx, and anesthetic management requires comprehensive preoperative evaluation and good anesthetic management without compromising bowel function. This optimizes splenic perfusion to reduce mortality ${ }^{(13)}$.
Since propofol used in anesthetic management has an antioxidant feature, it has been emphasized that it reduces intestinal-ischemic reperfusion injury. In case of intestinal ischemia- reperfusion injury, both oxidative stress and degranulation of mast cells play an active role. Gan et al. ${ }^{(14)}$ have suggested that inhibition of reactive oxygen species-mediated mast cell activation subsequent to attenuation of intestinal NADPH oxidase activation may represent a major mechanism by which propofol attenuates intestinal ischemic reperfusion injury. In their study in rats, they showed that propofol, similar to the antioxidant $\mathrm{N}$-acetylcysteine, inhibited reactive oxygen speciesmediated mast cell activation and attenuated intestinal ischemia-reperfusion injury and enhanced post ischemic mortality.

Ramisch et al. ${ }^{(15)}$ reported 3 early (first postoperative week) cases of mortality out of 42 patients (7\%) in their study. They worked on primarily long term outcomes. Chang et al. ${ }^{(16)}$ reported 4 cases or early mortality out of 15 patients $(26 \%)$ but they called "early death" if it happened within the first 6 months. These studies don't comply with our definition of early mortality which considers the deaths happening within the first 48 hours. Since we examined the anesthetic part of the cases, we defined early period mortality for deaths occurring within the first 48 hours. Our early mortality rate was 17 percent.

Our study has limitations such as small sample size and retrospective design. We think that more cases are needed for some parameters to be statistically significant.

In conclusion, there are many variables on mortality in small bowel transplantation patients. Perioperative anesthetic management is one of these variables. In order to reduce early period mortality, we think that hemodynamic and metabolic changes should be carefully monitored with proper anesthetic management during the perioperative period. We also believe that further studies should be done in terms of the effect of hemodynamic and metabolic changes occuring during perioperative period on graft perfusion. 


\section{Special thanks}

We would like to thank to all of the members of the transplantation team and especially Dr. Cezmi Karaca for their great efforts about small bowel transplantation.

\section{REFERENCES}

1. Lomax S, Klucniks A, Griffiths J. Anesthesia for intestinal transplantation. Continuing Education in Anaesthesia, Critical Care \& Pain. 2011;11:1-4. https://doi.org/10.1093/bjaceaccp/mkq043

2. Siniscalchi A, Piraccini E, Miklosova Z, Bagni A, D'Errico A, Cucchetti A, et al. Metabolic, coagulative, and hemodynamic changes during intestinal transplant: good predictors of postoperative damage?. Transplantation. 2007;84:346-50. https://doi.org/10.1097/01 .tp.0000275376.63674.1c

3. Siniscalchi A, Cucchetti A, Miklosova Z, Lauro A, Zanoni A, Spedicato $S$, et al. Post-reperfusion syndrome during isolated intestinal transplantation: outcome and predictors. Clin Transplant. 2012;26:454-60. https://doi.org/10.1111/j.1399-0012.2011.01530.x

4. Goldman LJ, Santamaría ML, Gámez M. Anaesthetic management of a patient with microvillus inclusion disease for intestinal transplantation. Paediatr Anaesth. 2002;12:278-83. https://doi.org/10.1046/j.1460-9592.2002.00826.x

5. de Oliveira Clark RM, Neto AB, Bianchi EH, de Carvalho LR. Evaluation of hemodynamic, metabolic, and electrolytic changes after graft reperfusion in a porcine model of intestinal transplantation. Transplant Proc. 2010;42:87-91. https://doi.org/10.1016/j.transproceed.2009.12.015

6. Siniscalchi A, Begliomini B, De Pietri L, Ivagnes Petracca S, Braglia V, Girardis M, et al. Pain management after small bowel/multivisceral transplantation. Transplant Proc. 2006;34:969-70. https://doi.org/10.1016/S0041-1345(02)02721-5

7. Siniscalchi A, Piraccini E, Cucchetti A, Lauro A, Maritozzi
G, Miklosova Z, et al. Analysis of cardiovascular, acid-base status, electrolyte, and coagulation changes during small bowel transplantation. Transplant Proc. 2006;38:1148-50. https://doi.org/10.1016/j.transproceed.2006.02.010

8. Piraccini E, Zanzani C, Caporossi E, Siniscalchi A, Dante A, Serri $\mathrm{T}$, et al. Intraoperative coagulation monitoring and small bowel transplantation: a way to explore. Transplant Proc. 2006;38,823-5. https://doi.org/10.1016/j.transproceed.2006.01.050

9. Planinsic RM. Anesthetic management for small bowel transplantation. Anesthesiol Clin North America. 2004;22:67585. https://doi.org/10.1016/j.atc.2004.06.007

10. Dalal A. Intestinal transplantation: The anesthesia perspective. Transplant Rev (Orlando). 2016;30:100-8. https://doi.org/10.1016/j.trre.2015.11.001

11. Cho SS1, Rudloff I, Berger PJ, Irwin MG, Nold MF, Cheng $\mathrm{W}$, et al. Remifentanil ameliorates intestinal ischemiareperfusion injury. BMC Gastroenterol. 2013;13:69. https://doi.org/10.1186/1471-230X-13-69

12. Gürkan A. Advances in small bowel transplantation. Turk $\mathbf{J}$ Surg. 2017;33:135-41. https://doi.org/10.5152/turkjsurg.2017.3544

13. Adachi K, Murakami N, Sasaki S, Kurosawa S, Horinouchi T, Kato M. Anesthetic management for two cases of living related small bowel transplantation. Masui. 2005;54:893-7.

14. Gan X, Xing D, Su G, Li S, Luo C, Irwin MG, et al. Propofol Attenuates Small Intestinal Ischemia Reperfusion Injury through Inhibiting NADPH Oxidase Mediated Mast Cell Activation. Oxid Med Cell Longev. 2015; Article ID 167014. https://doi.org/10.1155/2015/167014. Epub 2015 Jul 12.

15. Ramisch D, Rumbo C, Echevarria C, Moulin L, Niveyro S, Orce $\mathrm{G}$, et al. Long-term outcomes of intestinal and multivisceral transplantation at a single center in argentina. Transplant Proc. 2016;48:457-62. https://doi.org/10.1016/j.transproceed.2015.12.066

16. Chang HK, Kim SY, Kim JI, Kim SI, Whang JK, Choi JY, et al. Ten-year experience with bowel transplantation at seoul St. Mary's hospital. Transplant Proc. 2016;48:473-8. https://doi.org/10.1016/j.transproceed.2015.12.065 